\title{
Political Appraisals Constituting Tolerant versus Radical Identities: An Empirical Comparison between Dutch and British Muslims
}

\author{
Ertuğrul Gökçekuyu iD \\ Dr. Öğr. Üyesi, Necmettin Erbakan Üniversitesi, Siyaset Bilimi Bölümü, Konya, Türkiye \\ ertugrul.gokcekuyu@gmail.com
}

\begin{tabular}{ll}
\hline Article Info & ABSTRACT \\
\hline $\begin{array}{l}\text { Article History } \\
\text { Received: 22.03.2021 } \\
\text { Accepted: } 29.05 .2021\end{array}$ & $\begin{array}{l}\text { This article discusses the impact of the Dutch and British institutional trust on Muslim identity, their } \\
\text { political attitudes and the impact on their perceptions of conflict and peace. I demonstrate in this } \\
\text { Published: } 30.06 .2021 \\
\text { Keywords: identity, } \\
\text { the constitution of radical or violence prone identities. For this reason, I borrow one of the core } \\
\text { constructivism, conflict, } \\
\text { political trust, }\end{array}$ \\
$\begin{array}{l}\text { arguments of Constructivism that postulates that 'identities' can not be treated as fixed but must } \\
\text { rather be treated as 'socially constructed' valid variables in relation to conflict attitudes. This core } \\
\text { premise suggests that religious identities can be shaped by institutional imperatives constructing } \\
\text { either peaceful or conflictual identities. The constituted superordinate identities can be predicted to } \\
\text { be more tolerant to peaceful attitudes decreasing possible social tensions, whereas constituted rigid } \\
\text { identities can be predicted to be more prone towards perceptions of conflict and therefore the increase } \\
\text { of social tensions. This constructivist view allocates a significant role to identity-formation and how } \\
\text { attitudes of conflict can be impacted by the social context explaining a possible increase or decrease } \\
\text { of tensions. It is for this reason that Constructivism argues for constructs such as identity and } \\
\text { institutional support to be treated as equally explanatory indicators in the explanation of reduction or } \\
\text { increase of conflict in volatile domestic societies. }\end{array}$
\end{tabular}

\section{Siyasi Söylemlerin Oluşturduğu Radikal ve Tolerant Kimlikler: Hollanda ve İngiltere Üzerine Ampirik Araştırma}

\begin{tabular}{|c|c|}
\hline Makale Bilgileri & ÖZ \\
\hline $\begin{array}{l}\text { Makale Geçmişi } \\
\text { Geliş: } 22.03 .2021 \\
\text { Kabul: } 29.05 .2021 \\
\text { Yayın: } 30.06 .2021 \\
\\
\text { Anahtar Kelimeler: } \\
\text { kimlik, inşacıllk, } \\
\text { çatışma, siyasi güven, } \\
\text { kurumsal destek. } \\
\text { JEL Kodları: C15, J71 }\end{array}$ & $\begin{array}{l}\text { Bu araştırmanın amacı, Hollanda ve İngiltere gibi Demokratik Batı toplumlarında yaşayan } \\
\text { Müslüman bireylerin dinî ve siyasî kimliğini incelemektir. Batı'da varlığını sürdüren Müslüman } \\
\text { kimliğine aşırı sağcı akımlardan yansıyan tehditleri incelemek düşüncesi araştırmamızın ortaya } \\
\text { çıkmasında başrolü oynamıştır. Çünkü bu tehditler fiilen siyasî hayata yansıdığı gibi literatüre de } \\
\text { yansımaktadır. Ayrıca bu olumsuz tutumlar Batı'da Müslüman birey imajını zedelemekte ve genel } \\
\text { manada söz konusu bireylerin yaşadığı toplumda olumsuz ve çatışmacı kimlikler olarak okunmasına } \\
\text { neden olmaktadır. Yaptığım bu çalışma Müslüman kimliğinin siyasî kurumlara karşı tutumunu ve } \\
\text { algısını, bununla beraber bu kimliğin toplumsal rolünün hangi faktörler tarafından etkilendiğine } \\
\text { odaklanmaktadır. Bu çalışmamda kantitatif araştırma yöntemleri kullanılmıştır. Bu kullanımdaki } \\
\text { gaye ise, inşacılık teorisi üzerinden bahsi geçen iki köklü demokratik ülkeden elde edilen dataların, } \\
\text { literatürde geçen yapı ve ölçeklerin de kullanılarak analiz edilmesiyle sorunsala daha sağlıklı } \\
\text { bakabilmeyi sağlayacağı düşüncesidir. }\end{array}$ \\
\hline
\end{tabular}

Atıf/Citation: Gökçekuyu, E. (2021). Political Appraisals Constituting Tolerant versus Radical Identities: An Empirical Comparison between Dutch and British Muslims, Necmettin Erbakan Üniversitesi Siyasal Bilgiler Fakültesi Dergisi, 3(1), 68-81.

"This article is licensed under a Creative Commons Attribution-NonCommercial 4.0 International License (CC BY-NC 4.0)" 


\section{INTRODUCTION}

This article is based on the constructivist premise that identities are apt to change and that 'identities are not carved in stone' purporting the idea that identities are not only malleable, but also constitutive (Wendt, 1999, p. 21). Constructivism perceives the association between identities and institutions as interrelated and argues for an all-encompassing holistic approach wherein immaterial variables such as norms, ideas and identities are attained major explanatory roles. From this perspective Constructivism sets itself apart from materialist arguments and schools of thought such as neorealism and neoliberalism. Neither of the two approaches attain any significant explanatory value to immaterial constructs such as identity, ideas or norms. For that matter, it is first and foremost that it is constructivism that puts and assigns a central role to the concept of identity in the world of political sciences as a significant variable. Two, constructivism is not a political theory that refers only to International Relations (IR), but it is rather a holistic frame that in the words of Wendt should be treated as a social theory including political sciences. Finally, constructivism makes it possible to conduct research that explains why conflicts between identity groups increase or decrease. It should be clear by now that it is not my objective to discuss IR in this paper. It is however my objective to validate the significance of the constructivist premise that 'identities' are significant social constructs that as Jesse and Williams argue can be constituted by political institutional structures.

Therefore, we can infer that the constructivist approach accentuates how institutional support and political narratives can constitute conflictual or peaceful identities. Jesse and Williams have constructed their empirical research model on premises of constructivism in order to predict conflict reduction in volatile communities. Their research does not involve a model based on an IR-perspective, but rather focuses on the regional conflicts between the Catalans and Basks against the Spanish state and the Protestant-Catholic conflict in the United Kingdom. This paper borrows Jesse and Williams' constructivist postulations and demonstrates that their research in 'Identity and Institutions' argues that political narratives greatly impact the perception of trust by minority groups and play an important role in identity formations, affecting the perceptions of social order in terms of conflict or peace. Jesse and Williams' (2005) research on identity and institutions is one of the first serious empirical attempts to make the constructivist idea empirically applicable.

One of the contemporary political debates in the Western world is the incompatibility issue of the Muslim existence within democratic western countries. Cesari (2014) argues that the incompatibility argument coined by Wael Hallaq (2013) does not hold. She argues that many Muslim countries hold independent democratic elections with legitimate political parties, which is all by itself proof that the argument of Muslim incompatibility is irrelevant. As many scholars will remember this debate also resonates with Huntington's clash of civilizations. The idea is that Islam as a religion is not equipped to coexist with democratic norms making the Muslim individual unqualified, obscure and possibly jihadistic. These depictions are interrelated with the Muslim existence in Western countries as being secluded, disdained from the general welfare leading to strict police profiling by anti-terror laws and again strict immigration policies. Norris and Inglehart disagree with Huntington's whole thesis as being provocative and contentious. Norris and Inglehart (Inglehart \& Norris, 2004, p. 134) disprove Huntington's thesis Islam being the common denominator of all ethnic violence in the Middle East. Norris and Inglehart were able to disprove in their extensive research that there is no single Islamic culture around the world that could function as a common cause of violence. In the mean time scholarly works started to follow similar trails, such as Marranci (2011) who described the Muslim as a potentially dangerous agent and that the Muslim identity does not go well with western national identities proposing that Muslim individual with other loyalties, as the enemy within.

From this perspective Jesse and Williams' research proves to be essential and utmost important. The importance does not only concern reasons of applicability of the constructivist social theory, but all the more whether the Muslim identity as depicted above is not a by-product of the lack of political trust. It is therefore my ambition to build further on the applicability of the constructivist imperative by adapting and quantifying their theoretical model. My research therefore builds on three main variables identity, political salience and attitudes of conflict which are measured by 48 single items as a survey study in two consolidated democratic European countries. In order to reach a representative number of 
Muslim respondents in both countries, questionnaires are systematically and repeatedly distributed at the same time through official umbrella organizations, universities, educational institutions, foundations, unions, mosques and social media. A total of $\mathrm{N}=1312$ respondents was reached in a period of six months of which $\mathrm{N}=795$ Dutch and $\mathrm{N}=517$ were British respondents.

The composition of the respondents in the Netherlands is as follows: $34.9 \%$ Turkish, $23.40 \%$ Moroccan and $17.70 \%$ are of Dutch ethnic heritage. The composition of the participants in the United Kingdom is $25.7 \%$ of Bangladeshi, 22.8\% of Pakistani and 11.6\% of British ethnic heritage. In addition to the variable ethnicity, respondents in the United Kingdom indicate that $72.8 \%$ of the respondents have always lived in the United Kingdom whereas $94.8 \%$ of the respondents have always lived in the Netherlands.

\begin{tabular}{clll}
\multicolumn{3}{c}{ Table 1.Crosstab Country Country $* \mathrm{~N}=1312$} \\
\hline \multirow{4}{*}{ African } & NL & UK \\
Arab & & $6,60 \%$ \\
Asian & & $5,90 \%$ & $5,00 \%$ \\
Bengali & & $10,30 \%$ \\
British & & $25,80 \%$ \\
& Dutch & $11,60 \%$ \\
& Moroccan & $23,40 \%$ & $3,50 \%$ \\
& Pakistani & $1,00 \%$ & $22,90 \%$ \\
& Turkish & $34,90 \%$ & $2,90 \%$ \\
& Other & $22,10 \%$ & $11,40 \%$ \\
Total & & $100,00 \%$ & $100,00 \%$ \\
\hline
\end{tabular}

\section{THEORY AND LITERATURE REVIEW}

In the same line of thought, Wendt's emphasis in defining identity as "a relatively stable construct that seeks understanding and has expectations" (Wendt, 1992a, p. 397) suggests the individual search for stability in one's personal life. Becoming a member of a group entity can be explained to support this personal search by newly acquired norms, values and group support. Wendt (1992) embraces within constructivism the importance of process in the form of norms and values, stating that constructivism is applicable to all human conditions. Wendt also uses other theoretical frameworks such as the Social Identity Theory (SIT) to describe the functionality of an in-group or the membership to an in-group as a stabilizing factor for identity and process. But at the same time admits that this process of socialization is a long and slow interaction, since the individual needs time and space to find its place within the group structure. The process of socialization is based on interactionism wherein identities are constituted by group interaction. For Wendt SIT doesn't rule out collective identities which is why human beings construct societies and group identification, meaning that individuals learn to identify with each other as in the example of the European Union. This, for Wendt is proof for plasticity of group identities.

For Tajfel (1974) 'religious identity is a part of a person's social identity, therefore it is also a part of an individual's self-understanding'. This self-understanding comes from self-categorization and the awareness of the individual membership of an in-group. In SIT individuals are considered to have selfsufficiency in the selection of the own religious affiliation. Therefore, religious identity is neither something that is prearranged nor is this identity entirely free. Where SIT may explain individual identity and behaviour from an institutional perspective, there are scholars such as Jonathan Mercer who have heavily criticized and argued that the SIT actually defends the neorealist position criticizing Wendt's constructivism. For Mercer (1995) SIT explains the actors' natural self-interest that fear, conflict and 
therefore competition are expected outcomes in a realist-world over process and identity. Group memberships may hold individuals true to their shared values and commit to social roles that are stable and predictable. The ingroup socialization then will require members to share and internalize core values of the group. This may inherently mean that ingroup bias as in favouring the own group will occur and at the same time the group will start comparing itself with other groups, causing inter-group discrimination, violence and even conflict.

Another important scholarly approach is the work of Lijphart (2008), who explained social cleavages by way of vertical pillars, also called pillarization. This pillarization suggests, as occurred in the Netherlands during the fifties and the decades after that ethnic groups would compete with each other on basis of ideological differences. For Lijphart the concept of identity was not a relevant word of choice, whereas pillarization was solely built on the term ethnic cleavages. Lijphart did however stress the importance of such ethnically conflicting groups as being able to transcend their differences for collective gains in the form of consociationalism. As in constructivism de-pillarization does explain the decrease of conflict, whereas neither liberalism nor realism are able to explain the end of conflict.

From an empirical point of view the Brewer research shows that respondent's perception of themselves of having overlapping identities correlates with a certain degree of identity complexity. This high or low complexity of identity indicates respectively either an inclusiveness and tolerant attitude towards others or one that is exclusive converging identities into single dimensions. The Brewer (2013) research employs such attributes and social boundaries to determine memberships to groups. Therefore, it is the individual member's self-perception that is cognitive as well as motivational, which enables to predict inter- and intragroup relations. Therefore, the Brewer survey lets respondents to order their most important identities to establish self-perception. According to Brewer (2013) members of multicultural societies are much more inclined to positive and inclusive attitudes.

Both multiple as well as single identities may therefore become self-sustaining stable identities contingent of deep and established core beliefs, that may be positive, open and tolerant or be prone to conflict and violence. Therefore, identity in the political context does matter and can have devastating societal consequences, where cultural-religious groups may be forced to perceive to protect the self due to inter-group conflict and discrimination. In this sense such an unstable and confused state of identity has a higher chance to be deviant and conflict prone against populist and nationalist claims. This process may be more evident in socio-political despaired societies, as small ingroups may not have access to political resources or get institutional support and trust, which is required to reconstruct complex and tolerant identities.

\section{METHODOLOGICAL FRAMEWORK}

This article presents the quantitative part of a research that came about by way of triangulation using convergent parallel sequencing (Cresswell, 2012) for higher reliability and validity in research results. However, the qualitative data analysis is excluded for reasons of limited space. For the quantitative research method, a multistage sampling method is used where the questionnaire is randomly distributed to existing organizations by way of phone calls, e-mails and social media.

The questionnaire consists of forty-eight single item statements, which are constructed and adapted to existing scales in academic literature. The variable Muslim identity is measured by a scale used by Köktaş (2000) modelled according to the main pillars of the Islamic faith This scale is based on and composed of the five pillars and religious duties according to the Islamic faith. This scale is in line with the Onay scale (2000) and refers to the scales developed by Köktaş, who based his items on the research of the sociologist Hans Mol (1978).

This scale includes the minimum conditions of having a Muslim identity the Shahada, which encompasses the majority of the Sunni Muslim schools. For minority Muslim schools such as the Salafi movement, just the Shahada is not an adequate indication of having a Muslim identity and must therefore

\footnotetext{
${ }^{1}$ Shahada is the expression stated in accepting the Islamic faith ('there is no god but Allah, and Muhammad is the messenger of Allah') and it is known as one of the Five Pillars of Islam.
} 
be supplemented with Salaat (praying five times a day), fasting during the month of Ramadan, together with the duties of hajj and zakat. For this reason, certain questionnaire items are loaded together by a factor analysis to construct a new variable called 'Muslims Identity', which is presented on page 7.

Among other reasons the Netherlands and the United Kingdom are both consolidated democracies and both countries have large Muslim communities. There are 1.210.000 and 4.130.000 Muslims respectively living in the Netherlands and the United Kingdom. Both Muslim communities are flourishing and engaged in social-political life.

The questionnaire in this research includes socio-demographic questions such as age, gender, ethnic background, education and income and it is constructed according to a five-point Likert Scale. The questionnaire also includes questions on centrality and salience of Islam as to indicate the importance attached by the respondents' religious beliefs. Items on salience in the survey aims to measure the readiness of the respondents to act upon religious motives. This paper also explores a possible new scale to measure Muslim Identity by Principal Components Analysis (PCA) to view whether the single item, Shahada can be combined with the degree of importance attained to Islam, i.e. centrality and the item basing daily decisions according to Islam as this item covers the cognitive religious decision-making in daily life of respondents.

Further, the research of Brewer (2013) is employed to annotate the overlapping attributes to measure the flexibility respondents to tolerate other identities beside the own identity. Therefore, the Brewer scale is adapted into the questionnaire to analyse whether the Dutch and British Muslims perceive themselves to have single identity or multiple identities as to indicate rigidity (not-superordinate or single identity) and/or flexibility (superordinate and multiple identities) within their selfcategorization. Therefore, the respondents are asked whether they believe to have single identity or multiple identities. In case respondents perceive themselves as having multiple identities, they are then asked to order the most important three identities they feel that they belong to. Superordinate here, means that the respondent considers the Self to have a Muslim identity that is central and salient as well as also considering the Self to have a national identity such as being Dutch or British. This is labelled as having multiple identities where having a single identity means to be only Muslim and nothing else. This suggests that the respondent believes to have only one identity, that is the Muslim identity.

To measure the respondents' perceptions on the institutional trust and the how this variable correlates with the Muslim identity, a single item question is asked whether respondents perceive political actors trust Muslims and Islam (Hogg et al., 1995, p. 256). Jesse and Williams (2005) theorize that institutional trust is crucial as political actors' appraisals together with granting access to the political arena are imperative for constituting peaceful identities who then are predicted to become highly prone to embrace multiple identities instead of single and rigid identities. Another additional item that is included into the questionnaire measures the 'political salience' of the participants to measure their willingness to participate in political processes such as political parties, voting and having their own political parties in the national parliament.

\section{The Research Hypotheses}

As the scholarly attention in constructivism in the recent decades has been increasing, there is also much debate about the empirical applicability of constructivist paradigm (Wendt, 1999). Wendt and Onuf (2013) as the leading proponents of constructivism seem to disagree on this methodological issue. However, both agree that there is much need for empirical research. One serious scholarly work to theorize constructivism into an applicable frame belongs to Jesse and Williams (2005) who conducted a research on the Catalan-Bask conflict in Spain and the Protestant-Catholic conflict in the UK. Their research brought about an important finding that there is a positive association between variables identity and institutions and this association predicts the direction of a given conflict. Jesse and Williams finding supports Wendt's critique on neo-realism and neo-liberalism to fail to foresee or explain the end of the Cold War and therefore the end of such major conflict.

The first premise within the constructivist paradigm is that there are no taken for granted constructs such as 'fear' and 'threat' as being given, but these concepts are rather socially constructed. 
These 'assumed' deterministic built in factors such as fear, and threat become self-fulfilling prophecies and become self-sustaining as they are socially learned and carried over into the next generations. To build further on this premise; constructivism therefore suggests that if something is constructed, it can be reconstructed, redefined, and renegotiated within the social and political context. In this line of thought, identity and institutions are also malleable and therefore equally significant and relevant, contrary to the neo-realist and neo-liberal paradigms. Jesse and Williams also postulate a second determining factor in constituting 'multiple identities', which is the existence of cross-border institutions. As a condition, they postulate that such institutions must support multiple-identities and grant minority access to political resources. However, since there is no organized European Union (EU)level Muslim participation at the moment, this study focuses on the Muslim respondents' potential salience to access to the political domain and whether they perceive the existing political institution useful to support their Muslim identity.

This research model hypothesizes that Muslim identity in both countries does overlap with the much-debated variable 'national identity', such as being Dutch or British besides categorizing oneself as merely Muslim. As Jesse and Williams (2005) hypothesize, the institutional trust is an important variable in the constitution of new identities, the second hypothesis is that Muslim identity is open to be influenced by reflected appraisals of the political actor. Therefore, perception of the Muslim identity who feels trusted by the political actor can construct complex, multiple and superordinate identities. In addition to that as Brewer (2005) demonstrates individuals with superordinate identities are expected to be flexible and amiable, enabling open and tolerant behaviour towards out-group members. Then as Jesse and Williams would predict these socially constructed multiple identities, having been supported by institutional trust should inversely correlate with the variable of conflict (hard approach).

H1 The variable Muslim identity inversely correlates with the variable politicians' trust;

H2 The variable Muslim identity positively correlates with political institutional salience;

H3 The variable Muslim identity positively correlates with attitudes of peace;

\section{Socio-Demographic Data}

In the research conducted, $51.9 \%$ of the Dutch respondents $(\mathrm{N}=795)$ were male and $48.1 \%$ of the respondents were females. In the UK $58.2 \%$ of the respondents $(\mathrm{N}=517)$ were males and $41.8 \%$ were females. Overall respondents participating in the survey in both countries consisted of $60.5 \%$ males and $39.9 \%$ females. In both countries the proportion of males and females have comparable compositions, with a normal distribution across samples $(\mathrm{M}=1.39, \mathrm{SD}=0.49, \mathrm{P}<0.028)$ providing the data is significant and comparable.

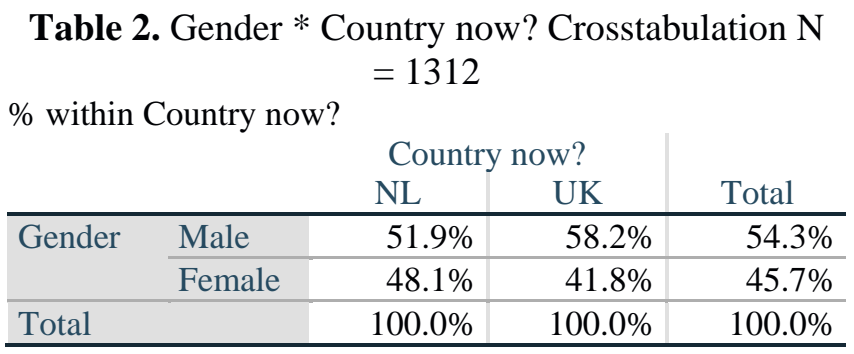

\section{Overall Data on Islamic Duties}

Data on religious duties in both countries demonstrate similar yet remarkably high percentages of salience in religious duties and obligations. The first question in the questionnaire is the statement on Islamic faith principles ${ }^{2}$ to ascertain whether the respondents agreed to be Muslim. 85.1\% of the Dutch

\footnotetext{
${ }^{2}$ The principles of Islamic faith concern the following principle conditions: 1) belief in Allah, 2) belief in Prophets, 3) belief in Books, 4) belief in Angels, 5) belief in the Judgement Day and 6) belief in Fate.
} 
respondents and $90.8 \%$ of the British respondents replied to perceive the principles of faith as extremely important.

Table 3. Pillars of Islam * Country? Crosstabulation $N=$ 1303

\begin{tabular}{llrr|r} 
& & \multicolumn{2}{c|}{ Country now? } & \\
& & NL & UK & \multicolumn{1}{c}{ Total } \\
\hline $\begin{array}{l}\text { Pillars of } \\
\text { Islam }\end{array}$ & Extremely & $85.1 \%$ & $90.8 \%$ & $87.3 \%$ \\
& Agree & & & \\
\cline { 2 - 5 } & Agree & $13.7 \%$ & $4.5 \%$ & $10.1 \%$ \\
\cline { 2 - 5 } & Neutral & $0.6 \%$ & $2.5 \%$ & $1.4 \%$ \\
\cline { 2 - 5 } & Disagree & $0.3 \%$ & $1.2 \%$ & $0.6 \%$ \\
\cline { 2 - 5 } & Extremely & $0.4 \%$ & $1.0 \%$ & $0.6 \%$ \\
& Disagree & & & \\
\hline Total & & $100.0 \%$ & $100.0 \%$ & $100.0 \%$ \\
\hline
\end{tabular}

Religious items such as Shahada, Salaat, Fasting, Hajj and Zakat, $88.2 \%$ of the Dutch and $90.3 \%$ of the British respondents replied as extremely important for the variable shahada. $77.1 \%$ of the Dutch and $70.2 \%$ of the British respondents replied to (salaat) praying five times a day as extremely important. $92.9 \%$ of the Dutch and $89.0 \%$ of the British respondents replied to fast always every year during Ramadan and $78.2 \%$ of the Dutch respondents and $80.8 \%$ of the British respondents replied to pay zakat always every year. On the other side $18.6 \%$ Dutch and 33.6\% of the British respondents responded to have fulfilled their hajj duty. These low percentages can be explained that hajj is contingent of financial means of the respondents.

\section{Type of Identities: Single or Multiple?}

To obtain an image of the perception on self-categorization of identity, the respondents were asked whether they perceive themselves as having 'only one identity' or 'more than one identity'. The table below presents that $45.5 \%$ Dutch and 53.7\% British Muslims categorise themselves to have only one identity. Whereas 54.5\% Dutch and 46.3\% British Muslims responded to have more than one identity. The difference between two countries is noticeable. British Muslims seem to be more inclined towards categorizing themselves as having 'single identity', whereas most Dutch Muslims categorize themselves as having 'multiple identities.'

Table 4. Identity $*$ Country now? Crosstabulation $N=1312$

\begin{tabular}{|c|c|c|c|c|}
\hline & & \multicolumn{2}{|c|}{ Country now? } & \multirow[b]{2}{*}{ Total } \\
\hline & & $\mathrm{NL}$ & UK & \\
\hline \multirow[t]{2}{*}{ Identity } & $\begin{array}{l}\text { I only have one } \\
\text { identity }\end{array}$ & $54.5 \%$ & $46.3 \%$ & $51.3 \%$ \\
\hline & $\begin{array}{l}\text { I have more than one } \\
\text { identity }\end{array}$ & $45.5 \%$ & $53.7 \%$ & $48.7 \%$ \\
\hline Total & & $100.0 \%$ & $100.0 \%$ & $100.0 \%$ \\
\hline
\end{tabular}

As it can be seen in the table below, when Muslim respondents were asked to order their most important three identities, $58.5 \%$ of the British Muslims list the British National identity in the first three ranks together with their Muslim identity. Oddly enough, British Muslims also score higher 58.5\% compared to the Dutch Muslims at a $48.8 \%$ level in multiple identities. Choice for single identity and high complex identity seem to contradict each other, yet as Brewer argued those who live in multicultural societies who are well aware of their own unique identities as well as of those of others are actually to have higher complex identities. 
It is also noteworthy to explain that respondents were only asked to bring an order in their own selfcategorized identities that they see fit for themselves. In other words, respondents were never asked to refer to any national identity whatsoever. Therefore, the data below are responses of respondents who from their own free will and self judgement categorized themselves as having a religious identity as well as a national identity, which in their cases meant to have Dutch/British national identities. In this sense this paper presents the finding that respondents who categorize themselves as Muslim also perceive themselves as Dutch/British categorically implicating a sense of loyalty towards the country they live in.

Table 5. Ordered $*$ Country now? Crosstabulation

$$
N=1312
$$

\begin{tabular}{llr|r|r} 
& & \multicolumn{2}{c}{ Country now? } & \\
& & NL & \multicolumn{1}{c}{ UK } & \multicolumn{1}{c}{ Total } \\
\hline Ordered & Yes & $48.3 \%$ & $58.5 \%$ & $52.5 \%$ \\
\cline { 2 - 5 } & No & $51.7 \%$ & $41.5 \%$ & $47.5 \%$ \\
\hline Total & & $100.0 \%$ & $100.0 \%$ & $100.0 \%$ \\
\hline
\end{tabular}

The first hypothesis (H1) that there is an inverse correlation between the variable Single Identity (I only have one single identity) and the variable politicians trust Muslims and Islam negatively correlate with each other $(\mathrm{M}=4.31, \mathrm{SD}=0.929, \mathrm{r}=-0.082 * *)$. Respondents across both countries who categorize themselves as having only one identity disagree with the statement that Dutch and British politicians trust Islam and Muslims.

Additional yet another important finding is that respondents who perceive themselves as having single identities present an inverse correlation with the variable attitudes of soft approach $(\mathrm{M}=1.84$, $\left.\mathrm{SD}=0.500, \mathrm{r}=0.201^{* *}\right)$. From this finding we may infer that those respondents who were able to order multiple (overlapping) identities to prefer an attitude of soft and peaceful attitudes. This finding provides supports the findings of Roccas and Brewer's findings as explained earlier.

\section{MUSLIM IDENTITY}

In order to construct a new variable called Muslim Identity is attempted by loading religious single item questions Shahada, Salaat, Fasting, Zakat and Hajj together by Principal Components Analysis (oblique rotation). This PCA analyses showed that the five items load well together with a determinant of 0.518 which is a fair score and considered to be significant. The Cronbach's Alpha is 0.596 which also shows a moderate internal consistency amongst the above single items.

Yet, a second way to construct a new variable Muslim Identity other than using the above single items, is to use other single items: Shahada, Centrality of Islam and Making Daily Decisions according to Islam. A PCA analysis provided a determinant-value of 0.475 (>0.0001). At this point I am able to assume that the three separated items can be factored together. The Kaiser-Meyer-Olkin Measure is 0.596, which is a significant score of validity (>0.0005). According to the KMO Bartlett's Test, the Factor analyses is strongly significant at a p-value of 0.000. The Cronbach's Alpha calculated for this new variable is 0.699 , which is a moderately strong internal consistency. This second construction of Muslim identity is statistically stronger and a better fit indicating that shahada, centrality of Islam and decision making on basis of Islam may construct a better fit for a new variable Muslim Identity.

\section{POLITICAL INSTITUTIONAL SALIENCE}

In order to measure the political institutional attitudes of the respondents, single item questions used in the questionnaire are loaded together by way of a PCA analysis. These items are (i) the 
respondent perceives voting as a part of his/her own identity, (ii) the respondent perceives to have equal rights, (iii) the respondent follows policies, (iv) + (v) desires own political parties in the national and European parliaments, (vi) +(vii) would rather vote for an own political party in national and European parliament, (viii) perceive lobbying policymakers as an important political institutional imperative. The PCA analysis delivers a determinant value of the Correlation Matrix 0.091 (>0.0001), which is a moderate value. The Kaiser-Meyer-Olkin value is 0.673 and significant at a level of 0.000 . The Cronbach's Alpha for these eight individual items was equal to 0.662 which is also a moderately fair indication of internal reliability.

Having composed a new variable called Political Intuitional Salience, this new variable positively correlates with the newly constructed variable Muslim Identity (Shahada, Centrality and Daily Decision by Islam): $(\mathrm{M}=3.90, \mathrm{SD}=1.427, \mathrm{r}=0.282 * *)$. Overall, the second hypothesis $(\mathrm{H} 2)$ that respondents with Muslim identity perceive democratic political salience can also be confirmed. As for the third hypothesis (H3) the newly composed variable Muslim identity positively correlates with the variable Soft Approach $\left(\mathrm{M}=1.84, \mathrm{SD}=0.920, \mathrm{r}=0.171^{* *}\right)$, which also conforms the third hypothesis, all correlations being significant at $\mathrm{p}=0.000$.

\section{POLITICIANS' TRUST ISLAM AND MUSLIMS}

When respondents were asked whether they agreed that the Dutch and British politicians trust Muslims or Islam, $45.1 \%$ of the Dutch Muslims and 36.3\% Extremely Disagreed with the statement. 69.4\% of the British Muslims and 18.6\% Disagreed. As it was also expected the variable politicians' trust in Muslims-Islam negatively correlated with the variable Muslim Identity $(\mathrm{M}=2.40, \mathrm{SD}=0.870, \mathrm{r}=$ $\left.-0.143^{* *}\right)$. The more respondents agreed to have a Muslim identity, the more they perceive the Muslim identity is distrusted by politicians.

Table 6. Politicians Trust in Islam and Muslims * Country now? Crosstabulation $N=1312$

\begin{tabular}{ll|r|r|r} 
& & \multicolumn{2}{c|}{ Country now? } & \\
& & NL & \multicolumn{1}{c}{ UK } & \multicolumn{1}{c}{ Total } \\
\hline Pol. Trust Islam \\
and Muslims & Extremely Agree & $0.6 \%$ & $3.1 \%$ & $1.6 \%$ \\
\cline { 2 - 5 } & Agree & $2.9 \%$ & $6.0 \%$ & $4.1 \%$ \\
\cline { 2 - 5 } & Neutral & $15.0 \%$ & $2.9 \%$ & $10.2 \%$ \\
\cline { 2 - 5 } & Disagree & $36.3 \%$ & $18.6 \%$ & $29.3 \%$ \\
\cline { 2 - 5 } & Extremely & $45.1 \%$ & $69.4 \%$ & $54.7 \%$ \\
\cline { 2 - 5 } Total & Disagree & & & \\
\hline
\end{tabular}

Another intriguing finding is the negative correlation between the variable politicians' trust and the variable of perceiving the self being recognized in society $\left(\mathrm{M}=1.49, \mathrm{SD}=0.500, \mathrm{r}=-0.326^{* *}\right)$. In other words, this correlation infers that the more respondents feel being trusted by politicians, the more they feel being acknowledged and recognized within the societies. Multiple Regression analysis shows that variables distrust of the political actor, lack of belief in having equal rights, feelings of discrimination and feelings of not being recognized deliver an R-square of 0.313 . We may infer that the lack of feelings of recognition in society can be predicted by these variables and account for $31 \%$ of the variance.

Table 7. Model Summary

\begin{tabular}{lc|c|c|c} 
Model & R & R Square & $\begin{array}{c}\text { Adjusted R } \\
\text { Square }\end{array}$ & $\begin{array}{c}\text { Std. Error of the } \\
\text { Estimate }\end{array}$ \\
\hline 1 & $.560^{\mathrm{a}}$ & .313 & .310 & .814 \\
\hline
\end{tabular}


a. Predictors: (Constant), Feel_recognized, Hard_Approach,

Pol_Trust_Isl, Feel_discriminated, Equal_Rights

The lack of being recognized in society can be explained by the negative appraisals of politicians towards Muslim minorities in both countries. This assumption is in line with the inverse correlation between the variable politicians' trust in Muslims or Islam and the variable feelings of being discriminated in society $\left(\mathrm{M}=2.57, \mathrm{SD}=1.025, \mathrm{r}=-0.306^{* *}\right)$. The more respondents feel to be distrusted, the more they feel discriminated in their society. Another significant finding that supports the latter is the negative correlation between the variable politicians' trust and the variable not feeling to be a valuable member of the society $\left(\mathrm{M}=2.30, \mathrm{SD}=0.982, \mathrm{r}=-0.283^{* *}\right)$. Further, the variable trust by politicians is also inversely correlated with the variable believing to having equal rights in society $\left(\mathrm{M}=2.68, \mathrm{SD}=1.055, \mathrm{r}=-0.338^{* *}\right)$. In other words, respondents in both countries experience politicians' distrust with perceptions of failure of recognition and discrimination and the failure of enjoying equal rights.

The variable politician's distrust is also inversely correlated with the variable salience to follow government policies $\left(\mathrm{M}=1.77, \mathrm{SD}=0.805, \mathrm{r}=-0.082^{* *}\right)$. From this it can inferred that Muslim citizen gets discouraged from political participation with feelings of alienation. In addition, the variable politicians' distrust is also inversely correlated with another variable where the wellbeing on the street is felt as being under threat $(\mathrm{M}=2.36, \mathrm{SD}=1.080, \mathrm{r}=-0.142 * *)$.

Finally, one of the most fundamental findings is that the variable distrust of the political actor positively correlates with the variable Hard Approach $\left(\mathrm{M}=3.84, \mathrm{SD}=1.218, \mathrm{r}=0.178^{* *}\right)$. The data shows that the more a respondent feels distrusted, the more a respondent perceives hard approach to be a suitable and viable social-political attitude. Hence, respondents who feel distrusted by the political actor, also perceive that they should be protected by Special Laws $\left(\mathrm{M}=2.45, \mathrm{SD}=1.176, \mathrm{r}=-0.114^{* *}\right)$ as the variable distrust and the need to be protected by special laws are inversely correlated.

\section{CONCLUSION AND DISCUSSION}

This article has proposed to provide an applicable model based on the constructivist premise of mutual constitutive effects between identities and institutions. The applicability of the constructivist theorem is a much debated and criticized topic in the world of grand theories of neo-realism and neoliberalism. Data analysed in this paper shows that respondents across both countries who categorize themselves as having only one identity disagree with the statement that Dutch and British politicians trust Islam and Muslims.

The worrying part is that respondents who perceive themselves as having single identities do not believe in soft approach, whereas respondents who perceive multiple and overlapping identities do prefer peaceful attitudes. This latter finding supports Roccas and Brewer's research findings that highly complex identities are tolerant and inclusive. Data analysed in this article has shown that negative appraisals of political institutions do matter and support the findings of Jesse and Williams' research findings that there is an association between identities and institutions.

As an example, data shows that respondents who feel being trusted by politicians, also feel being acknowledged and recognized within their societies. Whereas distrust of the political actor, goes together with perceptions that respondents lack having equal rights, feelings of discrimination and feelings of not being recognized. Data also shows that respondents believe that their wellbeing is under threat and that they need special laws to be protected. It may therefore be inferred that the constructivist 
argument may be justified as Muslim identity shows indications of the capability of being and having multiple identities and thus being malleable in relation to political actors' appraisal.

This paper additionally provides an alternative way to construct a variable to measure Muslim identity. This new variable Muslim identity provided a positive correlation in relation to the variable political institutional salience and with the variable soft approach. These data support the constructivist premise that identities are 'socially constructed'. Identities are subject to change due to political narratives affecting either positively or negatively, where overlapping multiple identities may become prone to perceptions of conflict. Therefore, I argue that political institutional support of the Muslim identity will have a positive impact on constituting multiple and tolerant identities and therefore increase the chances of reducing social conflict. 


\section{BIBLIOGRAPHY}

Adams, I., Adler, E., Allen, H., \& Anderson, S. (2011). Abdelal, Rawi, Yoshiko M. Herrera, Alastair Iaian Johnston, and Rose McDermott (eds.), Measuring Identity: A Guide for Social Science Research. Cambridge University Press: Cambridge

Ahmet O. (2000). Religious Attitudes and Muslim Identity, with Reference to Turkish University Students. White Rose eThese Online. Erişim Adresi uk.bl.ethos.365414. https://libguides.usc.edu/APA7th/ dissertationthesis\#s-lg-box-22622238

Brewer, M. B., Gonsalkorale, K., \& van Dommelen, A. (2013). Social identity complexity: Comparing majority and minority ethnic group members in a multicultural society. Group Processes \& Intergroup Relations, 16(5): 529-544.

Brewer, M. B., \& Pierce, K. P. (2005). Social Identity Complexity and Outgroup Tolerance. Personality and Social Psychology Bulletin, 31(3): 428-437.

Cesari, J. (2014). The Awakening of Muslim Democracy: Religion, Modernity, and the State. Cambridge University Press: Cambridge

Creswell, J. W. (2012). Educational Research: Planning, conducting, and evaluating quantitative and qualitative research. Pearson: UK

Duderija, A. (2007). Literature Review: Identity Construction in the Context of Being a Minority Immigrant Religion: The Case of Western-born Muslims. Immigrants \& Minorities, 25(2): 141-162.

Elshayyal, K. (2018). Muslim Identity Politics: Islam, Activism and Equality in Britain. Bloomsburry Publishing: London

Gilroy, P. (2000). Against race: Imagining political culture beyond the color line. Harvard University Press. Cambridge

Hogg, M. A., Terry, D. J., \& White, K. M. (1995). A tale of two theories: A critical comparison of identity theory with social identity theory. Social Psychology Quarterly, 58(4):255-269.

Hopkins, N. (2011). Dual Identities and Their Recognition: Minority Group Members' Perspectives. Political Psychology, 32(2): 251-270.

Huddy, L. (2001). From Social to Political Identity: A Critical Examination of Social Identity Theory. Political Psychology, 22(1). 127-156

Iner, D., \& Yucel, S. (2015). Muslim Identity Formation in Religiously Diverse Societies. Cambridge Scholars Publishing: New Castle

Inglehart, R., \& Norris, P. (2004). Sacred and secular. Religion and Politics Worldwide. Cambridge University Press. Cambridge

Jesse, N. G. (2005). Identity and Institutions. State University of New York Press: Ithaca

Lijphart, A. (2008). Verzuiling, pacificatie en kentering in de Nederlandse politiek. Amsterdam University Press: Amsterdam

Mamdani, M. (2005). Good Muslim, bad Muslim: America, the Cold War, and the roots of terror. Three Leaves Press Doubleday. New York.

Marranci, G. (2011). Jihad Beyond Islam. Berg Publishers. Oxford

McPhee, S. (2005). Muslim identity (Sussex Migration Working Paper No.34). University of Sussex. Erişim Adresi http://www.sussex.ac.uk/migration/research/publications/workingpapers/wplist

Meer, N., \& Modood, T. (2012). How does Interculturalism Contrast with Multiculturalism? Journal of Intercultural Studies, 33(2): 175-196.

Mercer, J. (1995). Anarchy and identity. International Organization, 49(2): 229-252. 
Mol, H., 1922-. (1978). Identity and religion: International, cross-cultural approaches. Sage Publishing: London

Nagel, J. (1994). Constructing ethnicity: Creating and recreating ethnic identity and culture. Social Problems, 41(1): 152-176.

Onuf, N. (2013). Making Sense, Making Worlds: Constructivism in social theory and international relations. Routledge: London

Peucker, M. (2018). On the (In)compatibility of Islamic Religiosity and Citizenship in Western Democracies: The Role of Religion for Muslims' Civic and Political Engagement. Politics and Religion, 11(3): 553-575

Pichler, F. (2005). Affection to and Exploitation of Europe: European Identity in the EU. (SSOAR Open Access Repository Working Paper). Erişim Adresi https://nbn-resolving.org/ urn:nbn:de:0168-ssoar-220567

Tajfel, H. (1974). Social identity and intergroup behaviour. Information (International Social Science Council), 13(2): 65-93.

Taylor, C. (1989). Sources of the self: The making of the modern identity. Harvard University Press: Cambridge

Van Klingeren, M., Boomgaarden, H. G., \& De Vreese, C. H. (2013). Going Soft or Staying Soft: Have Identity Factors Become More Important Than Economic Rationale when Explaining Euroscepticism? Journal of European Integration, 35(6): 689-704.

Wendt, A. (1992). Anarchy is what states make of it: The social construction of power politics. International Organization, 46(2): 391-425.

Wendt, A. (1999). Social theory of international politics. Cambridge University Press. Cambridge

Ysseldyk, R., Matheson, K., \& Anisman, H. (2010). Religiosity as Identity: Toward an Understanding of Religion From a Social Identity Perspective. Personality and Social Psychology Review, 14(1): 60-71

Yuval-Davis, N. (2006). Belonging and the politics of belonging. Patterns of Prejudice, 40(3): $197-214$. 


\section{EXTENDED ABSTRACT}

This article examines the impact of political institutional appraisals and how these appraisals influence the Muslim presence in the Netherlands and the United Kingdom. This quantitative study reveals that the variable politicians' trust in Muslims has great impact on the constitution of radical and violence prone identities. The research model is based on the constructivist premise postulating that 'identities' can not be treated as fixed but must rather be treated as 'socially constructed' variables. This premise therefore indicates that religious identities can be influenced by institutional imperatives constructing either peaceful or conflictual identities.

This study therefore argues that political appraisals can be used to predict the decrease of societal tensions, as well as predict conflict and therefore a possible increase of social conflict. This constructivist view allocates a significant role to identity-formation and how attitudes of conflict can be impacted by the political context. For this purpose, this article seeks to test the following hypothesis:

H1 The variable Muslim identity inversely correlates with the variable politicians' trust; H2 The variable Muslim identity positively correlates with political institutional salience; H3 The variable Muslim identity positively correlates with attitudes of peace;

One of the critical debates in the Western world today is the question of incompatibility of the Muslim existence within western countries. Many scholars will remember this debate resonating with Huntington's clash of civilizations. It is the idea that Islam as a religion is not equipped to coexist with democratic norms providing that the Muslim individual is unqualified, obscure and possibly jihadistic. These depictions are interrelated with the Muslim existence in Western countries as being secluded, disdained from the general welfare leading to strict police profiling by anti-terror laws and again strict immigration policies.

This research model hypothesizes that Muslim minorities in the Netherlands and the United Kingdom categorize themselves as being Dutch or British besides categorizing themselves also as Muslims. Jesse and Williams (2005) hypothesize from a constructivist perspective that the institutional trust is an important variable in the constitution of new identities. Therefore, it goes that the Muslim individual who feels trusted by the political actor will construct complex, multiple and superordinate identities. These identities being flexible and amiable, enabling open and tolerant behaviour towards out-group members. This model then predicts that these socially constructed multiple identities, being supported by institutional trust should inversely correlate with the variable of conflict (hard approach).

This article proposes to provide an applicable model based on the constructivist premise of mutual constitutive effects between identities and institutions. The applicability of the constructivist theorem is a much debated and criticized topic in the world of grand theories of neo-realism and neo-liberalism. Data analysed in this paper shows that respondents across both countries who categorize themselves as having only one identity (rigid identity) disagree with the statement that Dutch and British politicians trust Islam and Muslims. Probably the most worrisome part is that respondents who perceive themselves as having single identities do not believe in a soft approach, whereas respondents who perceive multiple and overlapping identities do prefer peaceful attitudes. This latter finding supports the constructivist premise that highly complex identities are tolerant and inclusive. Data analysed in this article shows that negative appraisals of political institutions do matter and support the findings of Jesse and Williams' research that there is an association between identities and institutions.

Data also demonstrates that respondents who feel being trusted by politicians, also can feel being recognized and acknowledged in the Dutch as well as British societies. However, the distrust of the political actor goes hand in hand with perceptions of absence of equal rights, the presence of discrimination and feelings of not being safe. This quantitative study therefore shows and argues that the constructivist argument is justified as the presence of the Muslim identity shows indications of the proficiency of constructing multiple identities and proving that identities are malleable in relation to political actors' appraisal.

Last but not least, this study provides an alternative way of constructing a variable to measure Muslim identity. This new way of measuring the variable of Muslim identity shows a positive correlation with the variable political institutional salience and with the variable soft approach. These data support the constructivist premise that identities are 'socially constructed' and that identities are subject to change on basis of political narratives affecting identities making these identities to be prone for perceptions of conflict. Therefore, this paper demonstrates that political institutional support of Muslim identity can have a positive impact on constituting multiple and tolerant identities and therefore increase the chances of reducing social conflict. 